\title{
Modern theological research: The authorship of the Byzantine anaphora of Saint Basil under investigation with the Thesaurus Linguae Graecae database
}

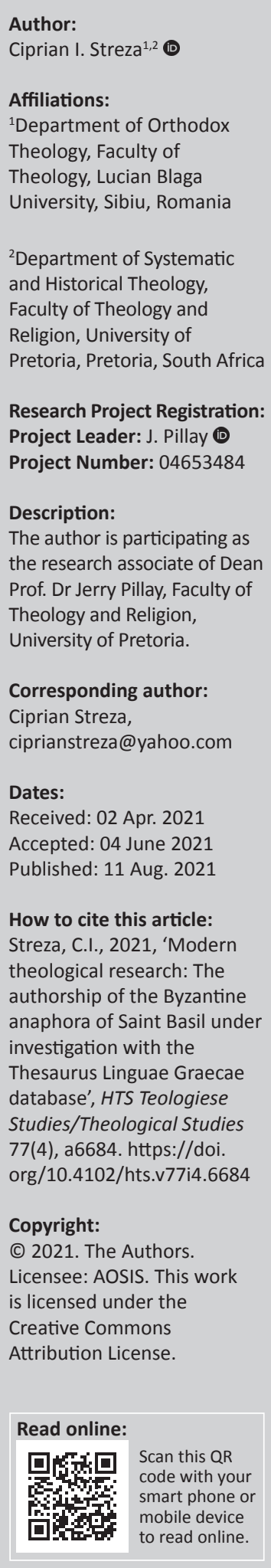

Saint Basil the Great wrote one of the most important and widely acknowledged Eucharistic texts in the Eastern Orthodox Church, a liturgical anaphora that bears his name. Before the dawn of the second millennium, this was the main Eucharistic text used in Constantinople and in the territories under its authority. In the modern time of digital media, the liturgical research methods have been improved by using the Thesaurus Linguae Graecae (TLG) database. The emergence of patristic and liturgical texts in this novel format was able to revolutionise the field of Comparative Liturgics, allowing to very quickly find the possible internal clues, which prove the basilian authorship of the anaphora bearing St. Basil's name. By the quick and accurate computer scanning of a part of the post-Sanctus prayer, a relatively complete picture of the relatedness of vocabulary, the author's theological and ascetical nomenclature, the recurring thought patterns, parallel passages and hapax legomena, rare terms and their frequency, is obtained.

Contribution: The present article aims to demonstrate that Theology has to be connected to modern research methods because the findings of such an academic approach are helpful for the development of ecumenical and interreligious dialogue, that is so well promoted by HTS Teologiese Studies/Theological Studies.

Keywords: Eucharistic anaphora; Saint Basil the Great; Comparative Liturgy; Thesaurus Linguae Graecae; Cappadocia; Eastern Orthodox Theology; Patristic Age.

\section{Introduction}

The Eucharistic text attributed to St. Basil the Great is amongst the most beautiful euchological formularies in the Eastern Orthodox rite, one in which the ineffable mystery of the divine love that was revealed in the redeeming sacrifice of the Son of God Incarnate is depicted in a liturgical poem of rare beauty (Arranz 1971:46-75). In the richness and diversity of biblical passages that are skillfully and harmoniously intertwined, in the careful structuring of the text and in the elevated style of the narrative, the author articulates an impressive theological viewpoint, in which the opposing pairs sin-death and life-redemption constitute the central ingredients in the liturgical ritual of giving God thanks for His love that was revealed in the Sacrifice of the New Adam (Ielciu 1986:68).

The fact that none of the Eastern Orthodox anaphoras had ever been so vastly spread or circulated in so many versions as the Eucharistic text ascribed to the great Archbishop of Caesarea in Cappadocia has represented a unique opportunity for the liturgical research to investigate the origins and evolution of the Christian Liturgy, as the history of this euchological formulary holds information on how the Eucharistic canon crystallised and evolved over time. The analysis of the history of this Eucharistic text was able to prove that its evolution went from simple to complex and from kerygmatic expressions to well-rounded theological and biblical formulations (Engberding 1931:LXXVI). In addition, the association of this euchological formulary, in all of its four versions, with the name of St. Basil the Great, has brought under discussion the possibility of questioning the authorship of this Eucharistic text.

Ninety years has passed since the issuance of Hieronymus Engberding's invaluable monograph on the anaphora of St. Basil the Great (Engberding 1931:1-89), and since then, many things have changed and the research in the field has significantly evolved from 1931 up to the present: new manuscripts have been discovered, older manuscripts have been critically edited - which made them easier to be studied comparatively (the new editions are presented here). Furthermore, liturgiology has become both an interdisciplinary science that takes into account the historical data and the dogmatic and spiritual input, and also a 'computerised science', having entered a new and

Note: Special Collection: Lucian Blaga University, Sibiu, Romania, sub-edited by Daniel Buda (Lucian Blaga University) and Jerry Pillay (University of Pretoria). 
challenging age of the digital media. The emergence of patristic and liturgical texts in this novel format was able to revolutionise the field of Comparative Liturgics and open new perspectives for its study. Just as Professor Robert Taft predicted and demonstrated programmatically in 1990, the possibility of authentication of liturgical texts by using the computer has now become an extremely useful and convincing work method,to raise questions or to validate or invalidate many hypotheses present in the status quaestionis of the greatest themes in the liturgical research. This same new work method will be employed in the present study as well, in an attempt to confirm Engberding's conclusions from 1931 stating that St. Basil had revised and expanded the ancient anaphora from Caesarea by adding biblical and Christological ingredients toit, by applying the methodological principles formulated in 1990 by Robert Taft and by using the Thesaurus Linguae Graecae (TLG) database in the analysis of a fragment of the post-Sanctus prayer.

\section{The authorship of the anaphora attributed to St. Basil the Great and the current liturgical research}

The subsequent paragraphs will only note the main scientific research connected to the authorship of St. Basil's anaphora, because a complete record of all the studies achieved on this subject would overwhelm this study.

Before the publication of Hieronymus Engberding's fundamental work in 1931, the liturgical research had mainly been concerned with the analysis of the evolution of the anaphora, rather than with establishing the authorship of this Eucharistic text. In his doctoral dissertation defended at Bonn, a Benedictine monk from Joseph Coesfeld Monastery was able to complete a thorough investigation of all (!) the manuscripts of St. Basil the Great's anaphora, which had been preserved in the languages of all Oriental and Eastern Churches (Arabic, Armenian, Ethiopian, Georgian, Greek, Slavic, Syrian and the Bohairic and Sahidic dialects). To do that, he set the scheme for their historical evolution; he brought to light their relationships with one another and indicated that Basil was the reviser of the ancient anaphora of Cappadocia, and thus he gave birth to a euchological text that bears his name (Engberding 1931:I-Lxxxix).

The main conclusions of his research may be synthetically rendered as follows:

- Saint Basil the Great's anaphora was preserved in four significant versions: the Egyptian anaphora of Basil ( $\ddot{A})$ (in Greek, Coptic, Ethiopic), the Armenian (Arm), the Syrian (Syr) and the Byzantine one (Byz).

- The oldest is the Egyptian version, followed by the Armenian.

- The Syrian and the Byzantine versions appeared later and were derived from a unique archetype that Engberding denoted by $\Psi$.

- At the root of their redaction, $\Psi$ and the Armenian version share a common archetype, denoted by $\Omega$, which is a reworking by St. Basil the Great of an ancient euchological formulary originating from Caesarea in Cappadocia (Urgestalt), whose nucleus merged with other Egyptian liturgical elements (ägyptisches Heimatgut) and engendered the text of the Egyptian version ( $\ddot{\mathrm{A}})$.

- Saint Basil the Great's input enriched the theological and biblical content of this ancient formulary (Urgestalt), and thus he conceived the euchological text $\Omega$, which constituted the foundation for the Armenian, Syrian and Byzantine versions. Consequently, the anaphora of St. Basil the Great bears not only the name of the man who wrote it but also that of the one who arranged it (Engberding 1931:Lxxxv).

- The nucleus of the Egyptian version appeared, most certainly, before St. Basil the Great was born. Hence, this euchological text cannot be in any way related to the personality of this great and Holy Father. The fact that it bears his name can be assigned to an ancient custom that had people brand the liturgy of a metropolis after the name of one of its important bishops, such as the case of the liturgy of St. Mark and St. James. Therefore, in Engberding's opinion, $\ddot{A}$ is a faithful reproduction of the old liturgy from Caesarea, to which certain Egyptian traditional liturgical elements were added (Engberding 1931:Lxxxvi).

- However, the Benedictine liturgist does not exclude the possibility that the Cappadocian Eucharistic formulary entered the Egyptian liturgical tradition bearing not only the name of St. Basil but also the marks of the great hierarch's contribution to it. The fact that the text of the Armenian, Byzantine and Egyptian versions include, just before the Eucharistic anaphora, a prayer that most certainly was authored by St. Basil the Great (Engberding 1966:287-313; Taft 1978:364-369; Verhelst 1998:157-172), which contains a series of elements that are also present in $\ddot{\mathrm{A}}$, made the German liturgist tone down his opinion on the origins and development of this Eucharistic text (Engberding 1931):

\footnotetext{
In this case - writes Engberding - we have to imagine things this way ... Egypt borrowed from the North a Eucharistic formulary that was already impressed - in and outside the Eucharistic anaphora - with marks of a reworking by the hand of Saint Basil the Great (it is worth noticing the obvious fact that only $\ddot{A}$ and the Liturgy of Nestorius contain the

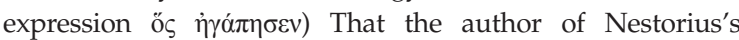
anaphora used a Byzantine euchological formulary belonging to Saint Basil the Great in the redaction of this Eucharistic text, is a certain fact that has been scientifically proven by Anton Baumstark. Also, the fact that only the text of the Egyptian version and of Nestorius's Liturgy contain the expression ös

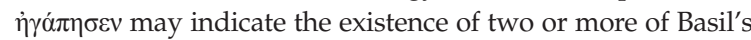
reworkings of the ancient Cappadocian euchological text that were acknowledged in the Eastern Liturgical Tradition. But this formulary had essentially kept the old form, whereas the other territories had adopted the new one. Yet these are but mere simple hypotheses. (p. Lxxxvi)
}

In other words, there is a possibility that the Egyptian text bearing St. Basil's name is the first concise reworking of the anaphora from Caesarea. There is also the possibility that 
the text of the archetype $\Omega$ represents, in this case, a more extensive elaboration of the same Cappadocian formulary, drafted later by the great Cappadocian father, who made it richer in meaning by adding some theological and biblical elements, and thus creating a new euchological formulary that eventually spread throughout the entire Eastern Orthodox world.

- The text arranged by St. Basil the Great suffered small retouches in the following four centuries, at the end of which it reached the form that is preserved in Codex Barberini gr. 336 [B] in the 8th century (eds. Parenti \& Velkovska 2000:1-14). Around the year 1000, an important Church figure of the age re-framed this Eucharistic formulary linguistically and stylistically and thus created a new euchological text that would later replace the old version (Engberding 1931:Lxxxvi).

The second most important development in the study of St. Basil's anaphora was the publication in 1960 of the Sahidic text of the Egyptian version (sah Bas), edited by Doresse and Lanne (eds. 1960:1-44). The said manuscript comprised a number of elements, which indicated that the narrative had enclosed an anaphora ascribed to St. Basil much earlier than any other liturgical text known by that date. In the preface to this edition, Bernard Capelle wrote that the same prayer could easily represent the text that was used by St. Basil himself before his death in 379 (eds. Doresse \& Lanne 1960:1). His statement also implied that Basil was, in fact, familiar with the Egyptian Basil, an assertion Engberding had never made in his work. The importance of the Sahidic text is capital for the study of the history of St. Basil's anaphora. A comparison of the latter part of the anaphora in the Doresse-Lanne manuscript, with the Brightman-edited Egyptian text from the manuscript Paris gr. 325, makes it possible to spot any existent discrepancies and make an estimate of how the Egyptian anaphora of St. Basil evolved between the 7 th and 14 th centuries.

The manuscript discovered by Doresse and Lanne was edited along with an essay by Capelle (1960:45-74), in which the French liturgist examined the verbal similarities existent between the Basilian anaphoras and the writings of Basil the Great.

Unfortunately, Capelle's examination stopped short before the institution narrative, and hence it included only the first half of the anaphora. Yet, this shortcoming was corrected to some extent by Bobrinskoy (1969:1-23). As he extended the comparison from the institution narrative, through the Epiklesis, and then to some of the intercessions, whilst taking into consideration the theological ideas and images in addition to the phraseology, Bobrinskoy further substantiated the relationship between Byz and its deemed author.

It is important to mention that, at the beginning of the 21st century, the anaphora of St. Basil became the focus of various significant new editions and major monographs. The critical edition of the Egyptian anaphora based on Greek and Coptic manuscripts was published in 2004 by Budde (2004). The two Armenian redactions were published by Renhart (2001) and Winkler (2005). The Byzantine Greek critical edition of the oldest manuscript, the Barberini gr. 336, from the 8th century was published by Elena Velkovska and Stefano Parenti in 2000 (eds. Parenti \& Velkovska 2000). Important contributions on particular problems of St. Basil's anaphora were published in the last years by Winkler (2008, 2011), Parenti (2020), Hauck (2015) and Vorhes McGowan (2011).

\section{Establishing today the authorship of a Eucharistic text - Methodological guidelines}

The emergence of written Eucharistic texts has been a longstanding process of anchoring and defining the oral tradition of the church. In the beginning, only the patterns of the liturgical celebrations were retained, upon which the words of the proestos were then grafted, who would improvise the content of the Eucharistic prayer in the given conditions. In time, however, the euchological formularies have come to be entirely transferred in writing for their safe-keeping and for the standardisation of the liturgical acts. This process managed at first to limit the amount of improvisation in the cult, and then to remove it altogether (Bradshaw 2002:73). The liturgical texts thus started to be disseminated, multiplied and adapted to the various local liturgical traditions. In the transcription of liturgical manuscripts, the copyists had to depart from the norms applied in the case of literary texts, and so they would oftentimes focus less on preserving the accuracy with the original and more on the correspondence between the texts and tradition, as well as with the practical liturgical reality of their time. Therefore, the Eucharistic anaphoras cannot be thought of as the work of a single church figure, but they are the result of the collective labour of the entire church (Baumstark 1923:71). In some cases, this common euchological material was arranged and reformulated by a great hierarch, which eventually led to the naming of that very Eucharistic text after its reviser (Baumstark 1908:771; Baumstark 1913:299-313). Yet, this proofreading process occurred within the confines of a welldetermined framework, as all the old anaphoras contained elements such as Epiklesis, anamnesis, instituting words, doxologies and hymns, which are all part of that 'given' of any Christian Liturgy. This actually inclined the process of proofreading mainly towards certain sections of the Eucharistic text, such as the Theological and the Christological Prayer, wherein the proestos was free to express himself in a more personal manner. Emmanuel Lanne asserts this in his reference to the text of St. Basil the Great's anaphora:

It is fit to believe that the first part of the anaphora, the one in which the priest could express himself in a more personal manner, is indeed the work of Saint Basil the Great. (Lanne 1982:319)

In the same context, Cuming (1984) affirmed that: 'Hence, a bishop from the 4th century had but little liberty of action and the contribution was practically materialized in specific 
short passages that were inserted in a given context' (p. 537). The same idea is also emphasised by Taft (1990:22), Budde (2004:50-56) and Parenti (2020:86-100). To establish, however, how and what the reviser contributed to the current form and content of the Eucharistic text bearing his name is a very difficult procedure, as it calls for means and methods other than those employed in establishing the authorship of a literary work. In the case of the Eucharistic text, its origins and evolution were influenced by many factors, and the contribution of the reviser was limited only to certain sections of it.

In the case of St. Basil the Great's anaphora, the aforementioned external arguments are many and obvious enough in indicating that the great Cappadocian father left his print on the Eucharistic text named after him. The internal arguments in favour of this hypothesis are still under scrutiny (Winkler 2008:112-126). In his 1990 study, Robert Taft was pointing to the possible internal clues to the authenticity of a Eucharistic text: the style, the propensity to use a certain vocabulary, the doublets and favoured spiritual loci (Taft 1990:21). The author indicated that the use of a certain specific terminology, the tendency to employ rare expressions and the preference towards some particular biblical passages were rather convincing internal arguments for the establishment of the authorship of a Eucharistic text, especially when they appeared in highly similar contexts (Taft 1990:23).

Robert Taft identified two major problems that made these internal arguments pass unnoticed. Firstly, the liturgical texts are living texts, 'subject to growth and changes that can obscure the traces of the original author's hand' (Taft 1990:22) and secondly, they are stereotypical, that is they are the fruit of the living tradition of the Church, and those who took the pains to put them in writing had to keep to a certain euchological scheme and to specific liturgical language patterns, generically called Formelgut. All the Eucharistic texts employ scriptural passages, all narrate in a specific language the entire economy of salvation, and all are marked by the fight against heresies (Taft 1990:23). Besides these two major issues, Robert Taft insists on pointing out that because of the general tendency to standardise the Eucharistic anaphoras, 'the most important liturgical texts may be the hardest to authenticate' (Taft 1990:24).

The methodological principles for the establishment of the authorship of a Eucharistic text can be synthetically rendered as follows:

1. All doublets attributable to another source or common to several authors and anaphoras, and hence possibly Formelgut, must simply be discounted as indices of authorship.

2. When there are noticeable correlations between the text of the anaphora and the works of a Church Father, then they are undoubtedly arguments for the authorship of the euchological formulary if, by performing a computer scan of all the patristic writings, it can be proved that those doublets belong exclusively to that Holy Father.
3. If such doublets occur exclusively in a compact block of paragraphs, both in the patristic literature and in the text of the Eucharistic anaphora, then the authorship can be assigned to the entire section of the Eucharistic text, and all the correlations contained within it turn into decisive arguments, even if their exclusivity cannot be demonstrated.

4. In the case of St. Basil the Great's anaphora, a special situation is posed by the Holy Father's inclination towards certain biblical passages that appear both in the liturgical text and in his own writings, as they were used in identical contexts, with the purpose to demonstrate one of this great Holy Father's original dogmatic ideas (Taft 1990:27).

All of these research methods can be applied only when the study is performed with the aid of the computer, by accessing the Thesaurus Linguae Graecae database and by using the digitalised format of euchological texts. Thesaurus Linguae Graecae is a research centre at the University of California, Irvine, which was founded in 1972. It represents the first attempt in the field of Humanities to produce a digital corpus of great magnitude, containing literary texts from Ancient Greek. Ever since its beginnings, this centre has collected and digitalised countless Greek texts, from Homer's works to authors contemporary to the fall of Byzantium in 1453. The TLG texts have been made available to the academic communities, first on magnetic tapes (in the mid 70s) and later on CD-ROMs. In the spring of 2001, the TLG centre developed its own proprietary search engine and made the TLG Corpus available online. Today, TLG Online contains over 117 million words in more than 11000 associated articles and is constantly updated and improved with new characteristics and texts (Thesaurus Linguae Graecae 2014).

\section{The structure of the Byzantine version of the post-Sanctus prayer}

The text of the Byzantine version of St. Basil the Great's anaphora belongs to the West Syrian liturgical family. In the Christological or post-Sanctus prayer, these anaphoras unveil the great mystery of the salvation of humankind diversely and within a rich thematic landscape.

The ineffable mystery of the divine love that was revealed in the redeeming sacrifice of the Son of God Incarnate is worded in the Byzantine version of the Eucharistic text attributed to St. Basil the Great, through a series of ingeniously intertwined biblical passages that combine into a Liturgical poem of unique beauty. Man's lapse into sin is narrated through excerpts from Psalms and the Book of Genesis, followed then by a mosaic of biblical texts extracted from the Pauline Epistles to the Philippians, Romans, Ephesians and Hebrews, which depict the fulfilment of the economy of salvation through the preparation of humankind, the Incarnation of the Son of God, His Sacrifice, Resurrection, Ascension to Heaven and Second Coming. Thus, the created theological vision is impressive; the opposition pairs sin-death and life- 
redemption constitute the core basis on which the liturgical ritual of giving God thanks for His love, revealed in the Sacrifice of the New Adam, is built. It is remarkable how, within the liturgical text, St. Basil the Great managed to associate the theme of knowledge, of discovering the truth in the Person of the Saviour, to the grand theme of life that is created and restored in Christ. This is furthermore proof that the great Holy Father did not care only to enrich a Eucharistic text theologically and biblically, but he meant to bring that text to the plenum and beauty of the original Eucharist (Bouyer 1966:289).

For the purpose of analysis, the text of the post-Sanctus prayer may be schematically divided in the following sections:

1. God's holiness and righteousness, the source of all gifts given to men

2. The creation of man

3. The fall into sin

4. The preparation of the world for the coming of the saviour

5. The fullness of time - the restoration of all things in Christ

a. The Person of the Saviour and the ineffable kenosis of His Incarnation

b. The accomplishment of salvation for the humankind: the Saviour's earthly life, Sacrifice, Resurrection, Ascension, the Second Coming and the consecration through water and the Spirit.

\section{The interpretation of the parallelisms between the text of the Byzantine version and the writings of St. Basil the Great in Section 4 by using the TLG database}

The analysis that the present study proposes starts from the premise that the writing proficiency of St. Basil the Great was par excellence biblical and liturgical at the same time. Beyond his vast knowledge of profane culture and skilful mastery of classic Greek, the great hierarch from Caesarea in Cappadocia was also a follower of Church tradition, a man of the experiential faith, who knew how to express - in the text of the Eucharistic anaphora, as well as in all of his writings what the Early Church lived and exhorted ever since the beginning. Given this fact, the attempt to establish the authorship of the Eucharistic text ascribed to him is no easy task. Saint Basil adopted the language of the liturgical tradition and tried to breathe a new theological and biblical spirit into the Eucharistic formulary that he used in the celebration of the Holy liturgy.

It is impressive how the great hierarch handled the arrangement of the Eucharistic text of his age, by cutting out certain expressions and rephrasing them, so as to make room for some ample dogmatic accounts, expressed by way of some original combinations of biblical verses. Thus, in Section 4 of the post-Sanctus prayer, which is to be analysed in the following paragraphs, an emblematic case appears in the Egyptian version $\ddot{A} g$ - the verb phrase '[You] did not

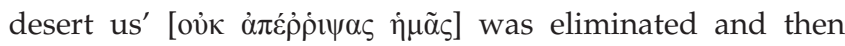
replaced in the Byzantine text with '[You] did not hide Yourself' [ov̉ $\gamma \grave{\alpha} \rho \dot{\alpha} \pi \varepsilon \sigma \tau \rho \alpha ́ \varphi \eta \varsigma]$, a reformulation inspired from Psalm 89, 46 (Engberding 1931:44).

The thematic structuring of the post-Sanctus prayer allows the entire economy of salvation to be described in an impressively coherent manner. Each great theological theme, such as the creation of man, the lapse into sin, the preparation of the world for the incarnation of the Saviour, the description of the Saviour's Person and of the work of salvation, has a corresponding section in the text of the anaphora, and the transition from one theme to another is performed in a consummate manner, thus making the whole text look like a vast and unitary poem.

On the basis of the thematic structuring of the text of the post-Sanctus prayer in the Byzantine version, the following paragraphs from Section 4 highlight the most important correlations between this euchological text and the writings of St. Basil the Great (cf. Table 1).

\section{Section 4: The preparation of the world for the coming of the Saviour}

In the Eucharistic anaphora, God's loving care for fallen men represents another ground for thankfulness. The Egyptian text [ ̈̈g] gives a succinct account, by means of a kerygmatic expression, of what the preparation of the world for the coming of the Saviour meant. In contrast to it, the Byzantine text presents, in an ample and profoundly theological manner, the way in which God showed His infinite goodness and mercy throughout the entire history of the chosen people. The text of the two versions will be presented side by side here, to emphasise the concision and simplicity of the Egyptian text in comparison with the complexity and theological elaborateness of the Byzantine one. Like in the whole text of the anaphora, it can be demonstrated that St. Basil had revised and expanded that ancient formulary from Caesarea, preserved in the Egyptian text [Äg], by adding theological, Christological and biblical ingredients to it.

In the Byzantine narrative, the idea stated in the short clause in the Egyptian text develops into a pretext for the enumeration of four distinct elements, which are deemed as defining for the entire Old Testament economy of salvation:

(1a) You sent forth prophets

(2) You performed mighty works by Your saints who in every generation have pleased You.

(1b) You spoke to us by the mouth of Your servants the prophets, announcing to us the salvation which was to come

(3) You gave the law to help us

(4) You appointed angels as guardians. 
TABLE 1: Comparative analysis of Section 4 of the Egyptian and Byzantine anaphora of St. Basil.

\begin{tabular}{|c|c|c|c|}
\hline \multirow{2}{*}{\multicolumn{2}{|c|}{$\begin{array}{l}{[\text { Äg] }} \\
\text { Renaudot I, pp. 63-71 }\end{array}$}} & \multicolumn{2}{|l|}{ [Byz] } \\
\hline & & Brightman, pp. 321-327 & \\
\hline 1 & 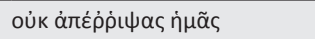 & 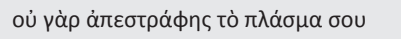 & 1 \\
\hline 2 & 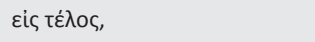 & 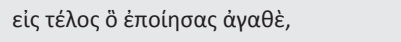 & 2 \\
\hline 3 & & 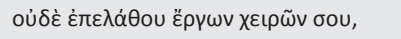 & 3 \\
\hline 4 & 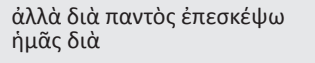 & 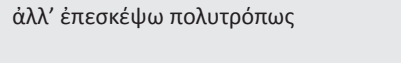 & 4 \\
\hline 5 & & 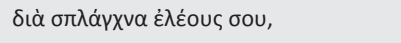 & 5 \\
\hline 6 & 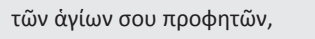 & 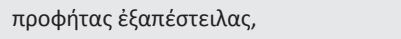 & 6 \\
\hline 7 & & 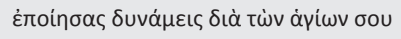 & 7 \\
\hline 8 & & 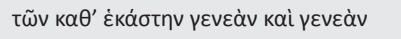 & 8 \\
\hline 9 & & 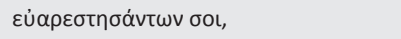 & 9 \\
\hline 10 & & 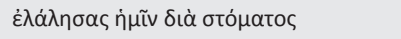 & 10 \\
\hline 11 & & 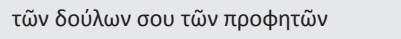 & 11 \\
\hline 12 & & 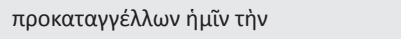 & 12 \\
\hline 13 & & 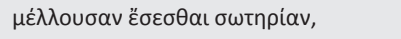 & 13 \\
\hline 14 & & 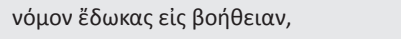 & 14 \\
\hline 15 & & 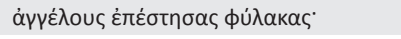 & 15 \\
\hline 1 & For You did not desert us & For You did not reject Your creature & 1 \\
\hline 2 & forever & forever, whom You made, O Good One & 2 \\
\hline 3 & $\begin{array}{l}\text { but You visited us throughout } \\
\text { the }\end{array}$ & $\begin{array}{l}\text { nor did You forget the work of Your } \\
\text { hands }\end{array}$ & 3 \\
\hline 4 & temp & but You visited him in various ways, & 4 \\
\hline 5 & through Your holy prophets, & because of Your tender compassion: & 5 \\
\hline 6 & & You sent forth prophets; & 6 \\
\hline 7 & & You performed mighty works by Your & 7 \\
\hline 8 & & saints who in every generation & 8 \\
\hline 9 & & have pleased You. & 9 \\
\hline 10 & & You spoke to us by the mouth & 10 \\
\hline 11 & & of Your servants the prophets, & 11 \\
\hline 12 & & announcing to us & 12 \\
\hline 13 & & the salvation which was to come; & 13 \\
\hline 14 & & You gave us the law to help us; & 14 \\
\hline 15 & & You appointed angels as guardians. & 15 \\
\hline
\end{tabular}

It is of significant importance that with the aid of the TLG database it can be easily proved that the listing of all these acts, through which God revealed His loving care for the fallen man, appears four times in the writings of St. Basil the Great and only in his writings and in no other work of a Church Father!

Here are the results:

a. In The Longer Rules, which he penned around the year 360, he recorded almost verbatim the following passage:

(3) He gave the law to help us

(4) He provided angels as guardians to watch over all

(1a) He sent forth prophets

[9] With warnings, He deterred man's impulses towards evil, and with promises He awakened his desire for virtue:

[A]nd then, after the first man was beguiled by the serpent, and was counselled into sin, and through sin met death, and through death misery, God did not forget him, but gave the law to help him and provided angels as guardians to watch over him, $\mathrm{He}$ sent forth prophets to warn against evil and preach the virtue, He deterred man's impulses toward evil with warnings, and with promises $\mathrm{He}$ awakened his desire for virtue; $\mathrm{He}$ forecautioned him about the end of evil and of virtue by recounting the lives of others, so that he may learn from them; yet despite all of these and many more of the like, He did not turn His back on those who persisted in their disobedience. (Basilius Caesariensis, Asceticon magnum sive Quaestiones [regulae fusius tractatae] PG 31. 913C)

b. In chapter 15, 39 from his Treatise on the Holy Spirit (ca 375), St. Basil the Great drew a concise picture of the entire economy of salvation of the humankind, by enlisting the following acts, by which God prepared the world for the coming of the Saviour:

[5] the blessings of the patriarchs

(3) the succour given through the legislation

[6] the types

[1] the prophecies

[7] the valorous feats in war

(2) the signs wrought through righteous men.

Whether you wish to examine ancient evidence - the blessings of the patriarchs, the succour given through the legislation, the types, the prophecies, the valorous feats in war, the signs wrought through righteous men... (Basilius Caesariensis 2002:386)

c. Letter 261 , dated 377 , contains the very same enumeration, yet in a larger context that also features other elements, which are defining for the Old Testament economy of salvation:

[5] firstly through the patriarchs

(3) Next for succour He gave the Law

(1b) then [He sent] the prophets, foretelling the salvation to come

[8] judges

[6] kings

(2) righteous men, doing great works in secrecy [with a mighty hand].

Next for succour He gave the Law, ordaining it by angels in the hand of Moses; then [He sent] the prophets, foretelling the salvation to come; judges, kings and righteous men, doing great works in secrecy [with a mighty hand]. After all these in the last days He [the Savior] was Himself manifested in the flesh, made of a woman, made under the law, to redeem them that were under the law, that we might receive the adoption of sons. (Basilius Caesariensis 1966:116-117)

d. In the Homily $V$ to the Hexaemeron, St. Basil the Great comments on the parable of the workers in the Vineyard (Mt 21, 33-40) and shows that the vineyard symbolises the souls of those who profited from God's uninterrupted merciful help, in the sense that they were surrounded by:

(3) the authority of His precepts

(4) a guard of angels

'I have planted a vineyard and hedged it round about' (Matt. 21,33). Evidently, He calls human souls His vine, those souls whom He has surrounded with the authority of His precepts and a guard of angels. (Basilius Caesariensis, Homilia in Hexaemeron 5. PG 29. 108C.)

Bernard Capelle wrote about these doublets in his pertinent study from 1960 (Capelle 1960:58-59), although he was unable to verify their exclusiveness. Today, this is possible 
because of the TLG database, and such proof is necessary because all the phrasal correspondences between the Eucharistic texts and St. Basil's writings could equally be credited to a common theological and liturgical language that is to be found both in the Church services and, typically, in the writings of the Church Fathers. For this reason, the proof of exclusiveness, that is, that a liturgical expression used in St. Basil's anaphora appears in no other patristic writing except for his indicates that it was he who inspired the euchological formulary that was named after him. The fact that almost all of the extra passages proved as exclusive to St. Basil are characterised by an elevated style, an outstanding mastery of the Greek language and an impressive theological depth (Hauck 2015:275-290), which cannot be commonly found in liturgical texts, shows that the great Cappadocian hierarch was the one whose authorial print is most visible in the text of the Byzantine anaphora.

A concise analysis performed on Section 4 of the postSanctus prayer, with the aid of the TLG database, indicates how contemporary theological research may benefit from the digitalisation of liturgical and patristic texts. In this extremely quick and efficient manner, within a short period of time, a series of correlations between the text of the Eucharistic anaphora and St. Basil the Great's works could be found. With the search evolving from simple key words to more complex expressions and then to entire phrases and sentences, the results highlighted impressive correlations, which were thus also proved to be exclusive. Such a research method opens new perspectives and horizons in the field of contemporary liturgical research (Boicu 2019:29-45).

The future of the modern theological research has been predicted almost three decades ago by Taft (1990) in his pertinent urge on the necessity of using in the future digitalised tools of research in liturgical studies, because:

Only via computerization can one get a relatively complete picture of the relatedness of vocabulary, the author's theological and ascetical nomenclature, recurring thought patterns, parallel passages, hapax lego-mena, rare terms and their frequency, all served up by this programming.... Computer scanning is not only quick, doing in minutes work that would take more than a lifetime, and with no guarantee of inerrancy. It also finds, with total accuracy, all doublets without exception... (p. 27)

\section{Conclusions}

1. In its endeavour to examine St. Basil the Great's anaphora, this study has employed and implemented the new and modern interdisciplinary research method proposed by Robert Taft back in 1990. With the aid of the TLG database, the study investigated all the thematic and lexical correlations existing in one section of the Byzantine anaphora between the liturgical text ascribed to this great Cappadocian father and his writings. The outcomes of this investigation show that the main ideas in the Christological prayer are also present, with the same highlights and sometimes even the same lexical identity, in some passages of St. Basil the Great's writings. Features such as the frequent use of biblical texts, the personalisation of the narration and the elevated style of the text, wherein the verbs play a defining role in creating antitheses, are typical traits of St. Basil the Great's writing skills that can definitely be found in the Byzantine Eucharistic text of the anaphora ascribed to him.

2. The present article reveals the fact that the act of determining the authorship of a liturgical text is a very complex process. In a common literary sense, liturgies do not have an author. Liturgies are fruits of the tradition, they are living texts, subject to growth, and later changes can obscure the traces of the original shape. Modern research methods can not only identify the thematic and lexical correspondences between the Byzantine and Egyptian versions of the anaphora and St. Basil's writings, but they can also prove the basilian authorship of the anaphora, by finding the exclusiveness of these similarities with the aid of a complex computer search. Most of the exclusive doublets are penned in an elevated classical language and imbued with remarkable theological insight and depth. The nonspecificity of these traits to the common liturgical language converts them into compelling arguments in favour of the Basilian authorship of the Byzantine Eucharistic text.

3. With the help of the modern research methods available today, the proposed analysis, in spite of being limited to only one section of the post-Sanctus prayer, confirmed Engberding's and Capelle's findings and proved once more that the Eucharistic texts had evolved from simple to complex and from a concise kerygmatic expression to an ample and theologically elaborate one.

The goal of the proposed comparative analysis is to show that, by employing the modern research methods made available by the TLG database, the findings of the liturgical research conducted in the last century on the topic of the authorship of St. Basil the Great's anaphora can be confirmed and even furthered.

\section{Acknowledgements Competing interests}

The author declares that he has no financial or personal relationships that may have inappropriately influenced him in writing this article.

\section{Author's contributions}

C.I.S. is the sole author of this research article.

\section{Ethical considerations}

This article followed all ethical standards for research without direct contact with human or animal subjects. 


\section{Funding information}

This research received no specific grant from any funding agency in the public, commercial or not-for-profit sectors.

\section{Data availability}

Data sharing is not applicable to this article as no new data were created or analysed in this study.

\section{Disclaimer}

The views and opinions expressed in this article are those of the author and do not necessarily reflect the official policy or position of any affiliated agency of the author.

\section{References}

Arranz, M., 1971, 'L'Économie du salut dans la prière du PostSanctus des anaphores de type antiochéen', La Maison-Dieu 106(1971), 46-75.

Basilius Caesariensis, 1966, 'Epistula 261', in Y. Courtonne (ed.), Saint Basile. Lettres, vol. 3, pp. 116-117, Les Belles Lettres, Paris.

Basilius Caesariensis, 2002, 'De Spiritu Sancto.16.39', in B. Pruche (ed.), Saint Basile de Césarée, Sur le Saint-Esprit, pp. 386-388, Sources Chretiennes 17bis, Les Belles Lettres, Paris.

Basilius Caesariensis, Asceticon magnum sive Quaestiones (regulae fusius tractatae), PG 31. 913C.

Basilius Caesariensis, Homilia in hexaemeron 5, PG 29, 108C.

Baumstark, A., 1908, 'Die Chrysostomusliturgie und die syrische Liturgie des

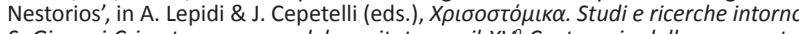
S. Giovani Crisostomo a cura del comitato per il XV Centenario della sua morte, pp. 771-857, Pontficium Institutum Studiorum Orientalium, Roma.

Baumstark, A., 1913, 'Zur Urgeschichte der Chrysostomusliturgie', Theologie und Glaube 5, 299-313.

Baumstark, A., 1923, Vom geschichtlichen Werden der Liturgie, Ecclesia Orans 10, Herder, Freiburg im Breisgau.

Bobrinskoy, B., 1969, 'Liturgie et ecclésiologie trinitaire de saint Basile', Verbum Caro 23, 1-23.

Boicu, D., 2019, “'Let none desert the church on my account". Some inconsistencies regarding the chrysostomic vision on the unity of the church', Review of Ecumenical Studies 11(1), 29-45. https://doi.org/10.2478/ress-2019-0003

Bouyer, L., 1966, Eucharistie. Théologie et spiritualite de la prière eucharistique, Desclée, Tournai.

Bradshaw, P.F., 2002, The search for the origins of Christian worship. Sources and methods for the study of early liturgy, Oxford University Press, Oxford.

Budde, A., 2004, Die ägyptische Basilios - Anaphora, Text - Kommentar-Geschichte, Jerusalemer Theologisches Forum 7, Aschendorff, Münster.
Capelle, B., 1960, 'Les liturgies "Basilienne" et Saint Basil', in J. Doresse \& E. Lanne (eds.) Un témoin archaique de la liturgie copte de S. Basile. En annexe: Les liturgies 'basiliennes' et saint Basile. Par Dom B. Capelle O. S. B, Bibliothèque du Muséon 47, pp. 45-74, Publications universitaires et Institut orientaliste, Louvain.

Cuming, G., 1984, 'Pseudonymity and authenticity, with special reference to the liturgy of St. John Chrysostom', Studia Patristica 15, 532-538.

Doresse, J. \& Lanne, E. (eds.), 1960, Un témoin arhaïque de la liturgie copte de S. Basile, Bibliothèque du Muséon 47, pp. 1-44, Publications universitaires et Institut orientaliste, Louvain.

Engberding, H., 1931, Das eucharistische Hochgebet der Basileiosliturgie, Textgeschichtliche Untersuchungen und kritische Ausgabe, Theologie des christlichen Ostens 1, Aschendorff, Münster in Westfalia.

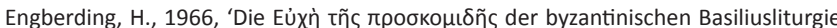
und ihre Geschichte', Le Museon 79, 287-313.

Hauck, J., 2015, 'Gott leibhaftig preisen, erzählen, erbitten. Zur Theologie der BasiliusAnaphora', Una Sancta 70, 275-290.

Ielciu, I.M., 1986, 'Viaţa şi valoarea ei după Sfinţii Părinţi Capadocieni', Mitropolia Moldovei şi Sucevei 1-2, 68-83.

Lanne, E., 1982, 'Les anaphores eucharistiques de saint Basile et la communauté ecclésiale', Irénikon 55, 307-331.

Parenti, S., 2020, 'Between anamnesis and praise: The origin of Oblation in SyroByzantine Anaphoras', Studia Liturgica 50(I), 86-100. https://doi. org/10.1177/0039320720906555

Parenti, S. \& Velokovska, E. (eds.), 2000, L' eucologio Barberini gr. 336, Bibliotheca Ephemerides Liturgicae Subsidia 80, pp. 1-14, Edizioni Liturgiche, Roma.

Renhart, E., 2001, 'Die älteste armenische Anaphora. Einleitung, kritische Edition des Textes and Übersetzung', in E. Renhart \& J. Dum-Tragut (eds.), Armenische Liturgien. Ein Blick auf eine ferne christliche Kultur, Heiliger Dienst. Ergänzungsband 2, Schnider, Graz-Salzburg.

Taft, R., 1978, The great entrance, Orientalia Christiana Analecta 200, Pont. Institutum Studiorum Orientalium, Roma.

Taft, R., 1990, 'The authenticity of the Chrysostom anaphora revisited. Determining the authorship of liturgical texts by computer', Orientalia Christiana Periodica 56, 5-51.

Thesaurus Linguae Graecae, 2014, A digital library of Greek literature, viewed 30 March 2021, from http://stephanus.tlg.uci.edu/Iris/indiv/stat.jsp.

Verhelst, S., 1998, 'La seconde partie de la deuxième prière de Saint Basil', Le Museon 111(1-2), 157-172. https://doi.org/10.2143/MUS.111.1.525706

Vorhes McGowan, A., 2011, 'The Basilian Anaphoras: Rethinking the question', in M. Johnson (ed.), Issues in Eucharistic praying in east and west: Essays in liturgical and theological analysis, pp. 189-219, Liturgical Press, Collegeville, MN.

Winkler, G., 2005, Die Basilius-Anaphora. Edition der beiden armenischen Redaktionen und der relevanten Fragmente, Übersetzung und Zusammenschau aller Versionen im Licht der orientalischen Überlieferungen, Anaphorae Orientales 2, Anaphorae Armeniacae 2, Pontificio Istituto Orientale, Rome.

Winkler, G., 2008, 'The Christology of the Anaphora of Basil in its various redactions, with some remarks concerning the authorship of Basil', in B.D. Spinks (ed.), The place of Christ in liturgical prayer, trinity, Christology and liturgical theology, pp. 112-126, Liturgical Press, Collegeville, MN.

Winkler, G., 2011, 'Über die Basilius-Anaphora', in M. Altripp (ed.), Byzanz in Europa. Europas östliches Erbe: Akten des Kolloquiums, Byzanz in Europa'vom 11. bis 15. Dezember 2007 in Greifswald, pp. 154-171, Brepols:Turnhout, Belgium. https://doi.org/10.2143/MUS.111.1.525706 